\title{
REPRESENTAÇÕES DO LUCRO NO COMÉRCIO DE ARTIGOS RELIGIOSOS: interpretações do sagrado e do profano no cotidiano das organizações
}

\section{1- Alessandro Gomes Enoque}

Doutor em Ciências Humanas (Sociologia e Ciência Política) pela Universidade Federal de Minas Gerais (FAFICH/UFMG), Brasil.

Professor da Faculdade de Ciências Integradas do Pontal (FACIP) da Universidade Federal de Uberlândia (UFU), Brasil. alessandroenoque@pontal.ufu.br http://lattes.cnpq.br/3430945807932551

\section{2- Jacquelaine Florindo Borges}

Doutora em Administração pela Universidade de São Paulo (FEA/USP), Brasil.

Professora do Programa de Pós-Graduação em Administração da Universidade Federal de Uberlândia (PPGA/UFU), Brasil. jac.borges@uol.com.br http://lattes.cnpq.br/9278983994605890

\section{3- Alex Fernando Borges}

Doutorando em Administração pela Universidade Federal de Lavras (PPGA/UFLA), Brasil.

Professor da Faculdade de Ciências Integradas do Pontal (FACIP) da Universidade Federal de Uberlândia (UFU), Brasil. alexfborges@gmail.com

http://lattes.cnpq.br/3169726160487491

\author{
Diego Maganhotto Coraiola - Editor Geral \\ Editor responsável pela submissão: \\ Diego Maganhotto Coraiola.
}

Artigo analisado via processo de revisão duplo cego (Double-blind).

Recebido em: 30/04/2014

Aprovado em: 10/07/2014

Última Alteração: 23/06/2014

* Contato Principal: Rua 20, n. 1600. Bairro Tupã, Ituiutaba - MG, Brasil. CEP 38304-402. 


\section{REPRESENTAÇÕES DO LUCRO NO COMÉRCIO DE ARTIGOS RELIGIOSOS: INTERPRETAÇÕES DO SAGRADO E DO PROFANO NO COTIDIANO DAS ORGANIZAÇÕES}

\section{RESUMO}

Nós analisamos quais são e de que modo são produzidas as representações sociais do lucro no comércio de artigos religiosos. A análise foi orientada por uma abordagem interpretativista, a qual pressupõe que partilhar representações é uma maneira de partilhar uma ideia e, assim, afirmar uma identidade e o pertencimento a um grupo. Estudos no campo da psicologia social e nos campos da sociologia e da antropologia fundamentam a pesquisa. Nós aplicamos o método de análise de conteúdo na análise de entrevistas realizadas com trinta comerciantes de artigos das religiões católica, evangélicas, espírita, umbanda e candomblé, de estabelecimentos localizados em quatro cidades. Os resultados mostram que o processo de geração do conteúdo representacional do lucro passa por diferentes defasagens: distorções, suplementações e subtrações. Desse modo, essa representação revela o seu caráter prático de ajuste do sujeito ao seu meio, de orientação da ação e de interpretação da experiência e organização da conduta no contexto material, moral e simbólico.

\section{Palavras-Chave}

Representações Sociais; Simbolismo; Religião; Imaginação Sociopsicológica; Conduta Moral.

\section{PROFIT REPRESENTATIONS IN THE COMMERCIALIZATION OF RELIGIOUS PRODUCTS: INTERPRETATIONS OF THE SACRED AND PROFANE IN ORGANIZATIONS EVERYDAY}

\section{ABSTRACT}

We analyze in this paper which and how social representations of profit are produced in the commercialization of religious products. The analysis is oriented by an interpretative approach, which presupposes that sharing representations is a way to share an idea, and, therefore, to affirm an identity and a belonging to a group. Studies in the fields of Social Psychology, Sociology, and Anthropology are the basis of this research. We used content analysis technique to analyze interviews with thirty organizations from the following religions: catholic, evangelic, spiritism, umbanda and candomblé, located in four cities. Results show that the process of generation of profit representational content undergoes different discrepancies: distortions, supplementations, and subtractions. And, thus, this representation reveals its practical character of adjusting the subject to its surroundings, its orientation of action, and its interpretation of the experience and of conduct organization in material, moral and symbolic contexts.

\section{Keywords}

Social Representations; Symbolism; Religion; Sociopsychological Imagination; Moral Conduct. 


\section{Introdução}

Os estudos no campo da Administração que buscam relacionar os fenômenos de natureza organizacional e a religião são ainda incipientes (Tracey, 2012). A despeito de uma rica tradição sociológica de estudos do universo religioso (Marx \& Engels, 2001; Durkheim, 2003; Weber, 2001, 2006), no campo da história das religiões e estudos sobre as distinções entre sagrado e profano (Eliade, 2008), as inter-relações entre Administração e religião são vistas, ainda, com estranhamento.

Estudos sobre essa temática foram publicados, nos últimos anos, descrevendo a influência da religião sobre o consumo, os impactos da religião no ambiente de trabalho, o papel da religião no processo de tomada de decisão, a relação entre religião e empreendedorismo, e a relação entre administração, religião e ética (Dodd \& Gotsis, 2007; Dyck \& Wiebe, 2012; Kauanui, Thomas, Rubens \& Sherman, 2010; Mitroff, 2003; Schwarzkopf, 2012; Serafim, Martes \& Rodriguez, 2012; Zelekha, Avnimelech \& Sharabi, 2014). Com o crescimento do número de estudos que pesquisam as relações entre Administração e religião emergem também análises críticas sobre a apropriação de conceitos e ideias do campo da religião em estudos de Administração (Boje, 2007, 2008; Tracey, 2012).

Nós analisamos, neste artigo, as representações sociais do lucro no comércio de artigos religiosos, quais são elas e de que modo elas são produzidas. A análise dos dados foi conduzida a partir de uma abordagem epistemológica interpretativista, visto que se adotou como pressuposto o fato de que as representações são "uma modalidade de conhecimento" (Spink, 1993) e que partilhar representações é uma maneira de partilhar uma ideia e, assim, afirmar uma "identidade" e o pertencimento a um grupo (Jodelet, 2001).

Estudos no campo da psicologia social e no campo da sociologia e da antropologia fundamentam a pesquisa. O método de análise de conteúdo foi aplicado na análise de entrevistas realizadas com trinta comerciantes de artigos das religiões católica, evangélicas, espírita e umbanda e candomblé, de estabelecimentos localizados em quatro cidades da região do Triângulo Mineiro (Uberlândia, Uberaba, Ituiutaba e Araguari).

Este artigo está estruturado em quatro seções, além desta introdução. Na próxima seção, nós revisamos as abordagens culturais da religião, com ênfase na relação entre religião e construção de significados. Em outra seção, desenvolvemos uma análise das representações e suas funções sóciosimbólicas. Nas duas seções seguintes, respectivamente, nós apresentamos os procedimentos metodológicos e a análise dos resultados sobre representações sociais do lucro no comércio de artigos religiosos. Em uma seção final descrevemos as implicações da pesquisa e apresentamos as conclusões.

\section{Abordagens Culturais da Religião: Interpretação da Experiência Religiosa e Gerencial e Organização da Conduta}

A análise do fenômeno religioso ocupou lugar significativo na obra de autores clássicos da sociologia (Marx e Engels, 2001; Durkheim, 2003; Weber, 2001, 2006). Esses estudos exerceram poderosa influência no debate da sociologia da religião e das organizações religiosas, moldando, em grande parte, as pesquisas contemporâneas sobre a temática (Tracey, 2012). Dentre as temáticas comumente tratadas nos universos da antropologia, da história e da sociologia da religião estão aquelas vinculadas às categorias do sagrado e do profano, entendidas como elementos centrais para a compreensão das modalidades de existência do homem no mundo (Durkheim, 2003; Weber, 2001, 2006; Bourdieu, 2007, 2008, 2010; Berger, 1985; Eliade, 2002, 2008).

A abordagem marxiana fundamentada no materialismo histórico e na crítica das relações econômicas de produção considera que o homem busca a religião como forma de suportar sua miséria real em um mundo dividido e alienado. Para Marx e Engels (2001), a religião é expressão e protesto contra o mundo real. Na abordagem marxiana, ela é o reflexo das relações de dominação de classe e de exploração e as ideias religiosas exprimem, justificam e escondem a realidade dessa dominação (Lesbaupin, 2010; Tracey, 2012).

$\mathrm{Na}$ abordagem durkheiminiana, de base funcionalista, o fenômeno religioso apresenta quatro características principais, das quais decorre sua função na vida social (Tracey, 2012). São elas: (a) é essencialmente coletivo; (b) abarca uma série de crenças e práticas; (c) religião e magia são formas sociais distintas e (d) o universo sagrado e o profano são distintos. Para Sanchis (2001), nos estudos de Durkheim (2003), a religião tem um caráter coletivo e a força religiosa tem origem no sentimento que a coletividade inspira em seus membros. Tal sentimento é projetado fora das consciências que o experimentam, e é objetivado na medida em que esse sentimento se materializa sobre um objeto, 
Representações do lucro no comércio de artigos religiosos: interpretações do sagrado e do profano no cotidiano das organizações

que se torna sagrado. É por meio do caráter ritualístico da religião que se dão a criação e a recriação periódica da fé. Em relação à distinção entre o sagrado e o profano, o primeiro configura-se como algo "afastado" das atividades do dia a dia, enquanto o segundo tem uma qualidade funcional, sendo usado ou consumido com um propósito particular. Desse modo, os objetos não são intrinsecamente sagrados, pois eles se tornam sagrados na medida em que são "acolhidos" por comunidades religiosas em situação específica que se repete ao longo do tempo.

Uma abordagem cultural da religião emerge em estudos weberianos e desenvolve-se a partir das ideias de racionalidade e de processo de racionalização (Mariz, 2010). Weber (2006, p. 125) tratou de diferentes tipos de racionalidade, especificamente do racionalismo ocidental, que se sustenta em um "processo crescente de intelectualização com elaboração de princípios, regras, critérios que pretendem ter validade universal e coerência interna, num projeto contínuo ao do matemático". Esse racionalismo ocidental expressava-se, para esse autor, de forma distinta nas diferentes esferas da vida, no sistema econômico e político e em toda a cultura, inclusive na própria religião. Ao buscar a compreensão acerca da propagação desse tipo de racionalidade, Weber (2001, 2006) defronta-se com a questão da religião, analisando a relação entre o protestantismo e a motivação para a racionalização da vida econômica. Nos estudos weberianos, os fenômenos do lucro e do trabalho assalariado são abordados em uma perspectiva cultural no contexto do protestantismo americano. O "capitalista empreendedor weberiano" é relativamente distinto dos seus predecessores (Martinelli, 1995), pois se caracteriza pela busca do ganho econômico, pela tolerância ao risco e pela subordinação do consumo à acumulação. Na abordagem weberiana, a religião atua como um elemento cultural essencial na conformação do "espírito capitalista".

Ainda nos estudos sociológicos, em uma concepção construcionista da existência humana, a religião ocupa lugar de destaque no empreendimento humano de construção do mundo (Berger, 1985). O "homem não possui uma relação preestabelecida com o mundo", conforme Berger (1985, pp. 18-19) o homem "se produz a si mesmo num mundo". Essa atividade humana de construção de um mundo e de significado da realidade "é sempre e inevitavelmente coletiva" (Berger, 1985, p. 20), um processo dialético que envolve três momentos: exteriorização (atividade física e mental sobre o mundo que torna a sociedade um produto humano); objetivação (ao tornar-se realidade sui generis, estruturas do mundo objetivo, exteriores e distintas dos produtores humanos, esses produtores se defrontam com tal realidade); interiorização (os homens se tornam produtos da sociedade; eles se reapropriam da realidade, que se torna estrutura da consciência subjetiva).

É desse empenho humano em construir um mundo de significado que surge a oposição entre cosmos e caos, sagrado e profano. O cosmos sagrado transcende o homem e também o inclui em sua ordenação da realidade; fornece-lhe "o supremo escudo" contra "o terror da anomia", contra o "pesadelo das ameaças do caos" (Berger, 1985, p. 40). Berger (1985, p. 41) conclui que "a religião desempenhou uma parte estratégica no empreendimento humano da construção do mundo", pois ela representa o ponto máximo daquela autoexteriorização e a tentativa de "conceber o universo inteiro como humanamente significativo".

No campo da história das religiões, Eliade (2008) argumenta que a compreensão dos conceitos de sagrado e profano somente pode ocorrer em uma perspectiva puramente relacional. Tais dimensões se comportariam como faces diferentes, porém, interdependentes, de uma mesma moeda, que se autoinfluenciam, especificamente em dois temas principais: o espaço e o tempo. Quanto ao espaço, pode-se argumentar que, ao contrário do que normalmente pensamos, ele não pode ser compreendido como sendo uma massa total amorfa e homogênea. Pelo contrário, para o homem religioso, o espaço constitui-se de modo não homogêneo, apresentando roturas e quebras, configurando porções qualitativamente diferentes das outras. Assim, tem-se um espaço caracterizado como sagrado ("forte", "significativo") e outro, profano ou não sagrado ("sem estrutura", "sem consistência"). Há, ainda, implícita na afirmação acima, a ideia de que o espaço sagrado é carregado de uma positividade inerente que se encontra ausente no universo profano. Tal positividade, gerada a partir de uma hierofania (Eliade, 2008), implica em uma consequente hierarquização dos espaços sociais.

Da mesma forma que o espaço não pode ser compreendido como algo homogêneo e nem contínuo, o tempo apresenta-se, também, estratificado nas dimensões do sagrado e do profano. Haveria intervalos de tempo sagrado, aqueles relacionados ao tempo das festas (em sua maioria, festas periódicas) podem ser caracterizados como tendo caráter circular, reversível, recuperável, ou seja, "[ ...] espécie de eterno presente mítico que o homem reintegra periodicamente pela linguagem dos ritos" (Eliade, 2008, p.64). Também haveria o tempo profano, compreendido pela "[ ...] duração temporal ordinária na qual se inscrevem os atos privados de significado religioso" (Eliade, 2008, 
p.63). Ainda de acordo com o mesmo autor, entre essas duas espécies de tempo existiria uma solução de continuidade, mas, por meio de ritos, o homem poderia passar de uma duração temporal ordinária para o tempo do sagrado.

Pesquisas foram realizadas sobre a relação entre sagrado e profano, no campo da sociologia da religião e da economia, analisando as escolhas de consumo e identidades religiosas (Cosgel \& Minkler, 2004) e a influência da religião sobre o consumo de bens religiosos e espirituais (Park \& Baker, 2007). No primeiro estudo, o consumo é analisado como uma forma de expressão das crenças dos indivíduos e das diferenças entre grupos e religiões existentes em uma sociedade. $\mathrm{O}$ consumo também é visto como uma maneira pela qual esses indivíduos expressam o seu comprometimento com uma determinada crença. No segundo estudo, analisa-se a influência da religião, dentre outros fatores, sobre o consumo de material religioso e mostra que ele se localiza em um campo intermediário entre pesquisas sobre consumo cultural e pesquisas sobre as práticas religiosas.

A respeito da análise cultural da religião, Edgell (2012) mostrou que se desenvolveram três correntes contemporâneas que contribuem para uma revitalização desse campo de pesquisa. A primeira corrente tem origem na perspectiva institucional, em estudos cujo interesse central é compreender de que modo as instituições modelam crenças e práticas religiosas e os tipos de mobilização que essas produzem. A segunda corrente, que inclui estudos neodurkheimianos, referese a uma abordagem da religião como algo vivido, cuja ênfase está na compreensão da experiência religiosa e em práticas contestadas de sacralização. A terceira abordagem dirige a atenção para os processos de legitimação simbólica da religião, com o estudo das fronteiras simbólicas e das ferramentas culturais da participação religiosa.

Em estudos no campo da antropologia, especificamente a partir do esforço de articular uma teoria cultural da subjetividade (Ortner, 2007), Geertz (2008, p. 91) propõe que o estudo antropológico da religião seja concebido em dois estágios: "no primeiro, uma análise do sistema de significados incorporado nos símbolos que formam a religião propriamente dita e, no segundo, o relacionamento desses sistemas aos processos sócio-estruturais e psicológicos." $\mathrm{Na}$ análise desse autor, a cultura tem como base dois conceitos e ideias: o ethos, que corresponde aos aspectos cognitivos, e uma "visão de mundo", que corresponde aos aspectos existenciais. O primeiro torna-se "intelectualmente razoável", explica Geertz (2008, p. 91), pois diz respeito ao tom, ao caráter e à qualidade de vida de um povo, e também ao seu estilo moral e estético, além de sua disposição em relação a ele mesmo e ao seu mundo. Já o segundo torna-se "emocionalmente aceitável", pois diz respeito ao quadro que esse povo elabora das coisas e de como elas são "na simples realidade", e também do seu conceito de natureza, do conceito de si mesmo e da sociedade. Essa "relação significativa entre os valores que o povo conserva e a ordem geral da existência dentro da qual ele se encontra é um elemento essencial de todas as religiões" (Geertz, 2008, p. 92).

Desse modo, a religião é "uma tentativa" de caráter implícito e diretamente sentida (em vez de explícita e conscientemente pensada) "de conservar a provisão de significados gerais em termos dos quais cada indivíduo interpreta sua experiência e organiza sua conduta" (Geertz, 2008, p. 91). Tais significados, ressalta o autor, são "armazenados" por meio de símbolos religiosos, os quais são dramatizados em rituais e relatados em mitos. Símbolos, rituais e mitos resumem, para aquele que crê, tudo aquilo que ele conhece sobre a "forma como é o mundo, a qualidade de vida emocional que ele suporta, e a maneira como deve comportar-se quem está nele" (Geertz, 2008, p. 91). Isso ocorre porque, conforme o autor, os símbolos sagrados vinculam uma ontologia e uma cosmologia com uma estética e moralidade.

A partir de meados dos anos 1970, houve um crescimento do interesse acadêmico pela temática da religião e pela relação entre o processo de secularização e a "pluralidade e revitalização" da participação religiosa em vários países (Chaves \& Gorski, 2001; Sherkat \& Ellison, 1999; Tracey, 2012). Conforme Tracey (2012), uma série de eventos sociopolíticos suscitou esse interesse, quais sejam: a emergência de um movimento conservador-evangélico nos EUA, o crescimento do pentecostalismo na África, na América Latina e em parte da Ásia, bem como o recrudescimento do islamismo. Esses eventos contribuíram para o crescimento, em décadas recentes, do número de estudos sobre crenças e práticas religiosas, visto que esses estudos, conforme Tracey (2012), permanecem necessários para a nossa compreensão das formas contemporâneas de organização.

Em estudos organizacionais, a religião oferece vários caminhos para a pesquisa acadêmica. Um deles, avalia Tracey (2012), é a relação entre "um tipo de moralidade" e "uma função crítica" assumida por agentes sociais de controle dessa moralidade religiosa; e a produção de demarcações dos comportamentos aceitáveis e inaceitáveis (misconduct). O autor também indica, como 
Representações do lucro no comércio de artigos religiosos: interpretações do sagrado e do profano no cotidiano das organizações

amplamente fértil para a pesquisa em administração, o papel do sagrado em organizações seculares e/ou quase religiosas, devido à presença, nessas organizações, de elementos característicos de organizações religiosas, como testemunhos, rituais, cerimônias, símbolos, conversão, liderança carismática, linguagem e simbolismo religioso de uma fé.

Também existem variadas possibilidades de pesquisa, inspiradas na abordagem bourdiesiana (Bourdieu, 2007, 2008, 2010) de campo religioso, como a religião como um locus privilegiado na competição pelos bens simbólicos e estudos da própria religião como negócio empresarial (propriedade de jornais, revistas, canais de televisão, entre outros). Todavia, ainda que pese o interesse por aquilo que aparece como algo comum às religiões no contexto do capitalismo contemporâneo, seria um equívoco tratar religiões distintas sem considerar suas especificidades (Almeida, 2011; Bairrão, 2002; Haag, 2011; Stoll, 2004; Valle, 2004).

\section{Representações Sociais: Compromisso Psicossocial e Imaginação Sociopsicológica}

No início do século XX, Durkheim $(1999,2003)$ mostrou que o simbólico é um elemento explicativo da realidade ao estudar as representações coletivas, bem como o papel dessas representações na vida social. Na obra desse autor, as representações coletivas são entendidas como um arcabouço teórico fundamental para as pesquisas sociológicas. Em sua análise sobre as formas elementares da vida religiosa, Durkheim (2003, p. 15) avalia que "os primeiros sistemas de representações que o homem produziu do mundo e de si próprio são de origem religiosa". As representações coletivas são produto do pensamento coletivo e possibilitam a compreensão das realidades coletivas.

Na abordagem durkheimiana, as representações coletivas nascem de um processo elaborativo, cooperativo e histórico, e não de seus indivíduos considerados isoladamente. Em decorrência desse processo cooperativo, sentimentos privados se transformam em "outra coisa" exterior e irredutível à dimensão particular. Para o autor, tais representações, de natureza independente do universo individual, emanam de sua natureza obrigacional e coercitiva/reguladora, como pode ser observado nas manifestações e nas práticas religiosas.

As múltiplas interdependências entre a vida privada e a vida social e entre as representações individuais e as representações coletivas também foram objeto de estudo no campo da psicologia social. Na segunda metade do século XX, com o objetivo de superar um passado de dicotomia individual e social, emergiram estudos nessa área, tendo por base o conceito de representações sociais (Farr, 1996; Jahoda, 1988; Jovchelovitch, 1996; Sá \& Arruda, 2000). O exame das relações entre o conceito de representações e outros conceitos e teorias que dizem respeito à ideologia, cultura, identidade e comunicação, dentre outros, possibilitou que ele fosse também aplicado aos estudos organizacionais (Lescura, Brito, Borges \& Cappelle, 2012; Borges, Medeiros \& Casado, 2011; Cavedon \& Pires, 2006; Silva, Carrieri \& Junquilho, 2011).

Representações sociais são, para Spink (1993, p. 300), "modalidades de conhecimento prático orientadas para a comunicação e para a compreensão do contexto social, material e ideativo em que vivemos". Ainda de acordo com a autora, essas formas de conhecimento "se manifestam como elementos cognitivos - imagens, conceitos, categorias, teorias", porém, "não se reduzem jamais aos componentes cognitivos", visto que são "socialmente elaboradas e compartilhadas e contribuem para a construção de uma realidade comum, que possibilita a comunicação" (Spink, 1993, p. 300). Ou seja, as representações sociais são, essencialmente, fenômenos sociais que, mesmo acessados a partir do seu conteúdo cognitivo, têm de ser entendidos a partir do seu contexto de produção, das funções simbólicas e ideológicas a que servem e das formas de comunicação onde circulam.

No âmbito dos estudos psicossociológicos, o conceito de representações sociais foi desenvolvido, nos anos 1960, por Moscovici (1988, 2007). Para ele, as representações sociais correspondem a uma modalidade de conhecimento "prático", do "dia a dia". Para este autor, a transformação de uma ideia ou o poder das ideias é um tema central da psicologia social, existindo uma relação irredutível entre o conhecimento social e as interações, pois o primeiro é sempre produzido por meio da interação e da comunicação e a sua expressão está vinculada aos interesses humanos, que estão implicados naqueles.

Para Moscovici (2007, p. 34), as representações sociais têm duas funções. Na primeira função, elas "convencionalizam os objetos, pessoas ou acontecimento". Tais convenções (que dependem, em geral, de convenções preliminares e subjacentes) definem fronteiras e possibilitam que indivíduos e grupos resolvam problemas cotidianos quando a interpretação de uma mensagem, 
como significante, em relação à outra, não significante, produz experiência que é somada a uma realidade predeterminada. Na segunda função, as representações sociais "são prescritivas" (Moscovici, 2007, p. 36-37). Tais prescrições estão presentes nos diversos aspectos da vida social desde antes de nascermos. Por serem partilhadas por tantas pessoas, cada um de nós as assume como "respostas prontas" para os problemas; à medida que elas penetram e influenciam cognitivamente cada um, elas são "repensadas, recitadas e reapresentadas". As ideias passadas são ideias ativas que infiltram e mudam as ideias atuais, as quais, ao serem mudadas, adquirem nova existência. Assim, estudar representações sociais é estudar o ser humano e sua busca por compreender e comunicar (Moscovici, 2007).

A primeira etapa de elaboração das representações sociais foi denominada "ancoragem", por Moscovici (2007, p. 68), e implica classificar e dar nomes a pessoas, coisas e acontecimentos. Nessa etapa, os indivíduos em grupos classificam objetos, mediante escolha de um dos paradigmas ou protótipos estocados na memória, com o qual comparam o objeto a ser representado e, então, decidem "se ele pode ou não ser incluído na classe em questão" (Sá, 1993, p. 38). A ancoragem não se refere tão somente a um processo de rotulação ou graduação de pessoas ou coisas como "entidades discretas". Conforme explica Moscovici (2007, p. 70), o "objetivo principal é facilitar a interpretação de características, a compreensão de intenções e motivos subjacentes às ações das pessoas, na realidade, formar opiniões".

A segunda etapa da formação das representações sociais foi denominada, por Moscovici (2007), de objetivação, o processo de "descobrir a qualidade icônica de uma ideia" e "reproduzir um conceito em uma imagem" (Moscovici, 2007, p. 71-72). Para Spink (1993, p. 306), esta "é essencialmente uma operação formadora de imagens, o processo através do qual noções abstratas são transformadas em algo concreto, quase tangível". A objetivação "consiste em uma operação imaginante e estruturante, pela qual se dá uma forma - ou figura - específica ao conhecimento acerca do objeto, tornando-o concreto, quase tangível" (Sá, 1993, p. 39). Ou seja, o processo de objetivação implica a cristalização dos universos simbólicos de uma determinada sociedade. A etapa de objetivação ocorre em três estágios (Moscovici, 2007, p. 72-75; Jodelet, 2001, p. 38) que são: (a) construção seletiva: a seleção das imagens que podem se associar a uma ideia (considerando situações de ausência de imagens ou de tabus), as quais são integradas a uma "núcleo figurativo" ou "complexo de imagens" que reproduzem o complexo de ideias; (b) esquematização estruturante: a imagem é assimilada totalmente, de modo que o que é percebido substitui o que é assimilado; as imagens "se tornam elemento da realidade, em vez de elementos do pensamento" e (c) naturalização: as imagens existem como objetos, ou seja, são o que significam.

As representações sociais, assim, tornam "o não familiar, em algo familiar" (Moscovici, 2007, p. 78), portanto, é a maneira pela qual os indivíduos e grupos lidam com as incertezas, com o estranho, a ansiedade e a memória. A ancoragem dirige a memória para dentro, em um processo em que coloca e tira objetos, pessoas e acontecimentos, classifica-os e dá-Ihes nome. A objetivação mais ou menos dirigida para fora - para os outros - busca e tira conceitos e imagens (constituintes), os junta a outros já conhecidos (constituídos) e os reproduz no mundo exterior. Para Jodelet (2001, p. 20), as representações "se inscrevem nos quadros de pensamento preexistentes e enveredam por uma moral social". Elas são formas de lidar com os perigos físicos/biológicos e morais, portanto, guiam ações e trocas cotidianas. Por se constituírem "sistemas de interpretação que regem nossa relação com o mundo e com os outros", as representações sociais "orientam e organizam as condutas e as comunicações sociais" (Jodelet, 2001, p. 22).

A representação social tem com o seu objeto (coisa) ou alguém (pessoa) uma relação de "simbolização", substituindo-o, e de "interpretação", conferindo-Ihe significado (Jodelet, 2001, p. 27). Suas funções e eficácia sociais dependem de seu papel no "ajustamento prático do sujeito a seu meio", também chamado de "compromisso psicossocial" (Jodelet, 2001, p. 28) e do seu papel para a ação, chamado de "imaginação sociopsicológica" (Duveen, 2007, p. 27). O partilhamento das representações sociais, ou seja, de "uma ideia ou uma linguagem", é uma maneira, portanto, de "afirmar um vínculo social e uma identidade" (classe, partido político e religião), ou seja, as representações sociais engendram solidariedades e ajudam a entender os aspectos cognitivos "que constituem a matéria e a trama da vida social" (Jodelet, 2001, p. 34). De acordo com o estatuto epistemológico das representações sociais, estas se caracterizam por seu "caráter prático", o que implica em estar "orientado para a ação e para a gestão da relação com o mundo" (Jodelet, 2001, p. 36).

Por estar a serviço dos interesses, das necessidades e dos desejos dos grupos e serem expressivas dos sujeitos, as representações estão sujeitas a defasagens, pois passam pela intervenção de valores, códigos coletivos, implicações pessoais e engajamentos sociais dos 
Representações do lucro no comércio de artigos religiosos: interpretações do sagrado e do profano no cotidiano das organizações

indivíduos. Para Jodelet (2001, p. 36), essa intervenção produz "três tipos de efeitos" nos conteúdos representativos (Figura 1 ), que são:

(1) distorções: ocorrem quando todos os atributos dos objetos estão presentes, porém, eles estão acentuados ou atenuados para reduzir a distância entre a representação e as qualidades socialmente desejadas e/ou esperadas para um objeto, ato ou pessoa;

(2) suplementações: ocorrem quando são conferidos aos objetos representados atributos e conotações que não Ihes são próprias, produzindo um acréscimo de significações socialmente apreciadas como positivas ou negativas; e

(3) subtrações: ocorrem quando atributos pertencentes ao objeto são suprimidos, em geral, devido à repressão e/ou à pressão de normas sociais.

Nós analisamos, neste artigo, os aspectos relacionados à formação e ao caráter prático das representações sociais. A Figura 1 ilustra as etapas e as funções das representações sociais, conforme estudos de Moscovici (2007), Jodelet (2001) e Wagner et al. (1999). Todavia, deve-se considerar que a Teoria das Representações Sociais, inaugurada por Moscovici, está sujeita a críticas (Jahoda, 1988; Howarth, 2006).

Uma dessas críticas diz respeito à natureza das contribuições das representações sociais para a ordem ou a transformação social. De acordo com Spink (1993, p. 305), o estudo das representações sociais mostra, a "concomitância de conteúdos mais estáveis e de conteúdos dinâmicos, mais sujeitos à mudança". As representações sociais constituem, assim, palco tanto de permanências culturais, quanto de diversidade e instabilidade. Tal diversidade levaria, segundo a autora, à compreensão das representações sociais como um fenômeno fundamentalmente processual, com a função social de criação e manutenção de uma determinada ordem social.

Os estudos sobre a dinâmica das representações mostraram que não se pode desconsiderar que "toda representação se organiza em torno de um núcleo central" ou "núcleo estruturante" e por elementos periféricos (Abric, 2001, p. 163). O núcleo central tem uma função geradora (responsável pela criação ou transformação de significados) e uma função organizadora (responsável pela natureza dos vínculos dos elementos da representação, produz unificação e estabilização). Todavia, quando um discurso ideológico está em desacordo com uma representação, as práticas sociais embasadas nesse discurso podem promover ou desencadear transformações profundas e violentas nas representações constituídas (Flament, 2001). Inicialmente, as discordâncias se "inscrevem nos esquemas periféricos" das representações, que se modificam e, por algum tempo, protegem o núcleo central. Todavia, se existe contradição explícita entre práticas e representação, se essa discordância se amplia e se aprofunda, o núcleo central poderá ser atingido e estruturalmente modificado, gerando uma transformação concreta e brutal nas representações. Nessa relação entre - conceito "representações sociais" e as práticas sociais está o potencial crítico do primeiro, contraponto da ideia de seu papel estabilizador e regulador (Howarth, 2006).

Em resposta à crítica sobre o papel das representações para a ordem ou a transformação, Howarth (2006) avalia que a Teoria das Representações Sociais tem se desenvolvido em dois campos: uma teoria moderna da mudança social e também uma teoria do conhecimento social. A autora afirma que essa teoria pode proporcionar um caminho para a crítica da ordem social e das relações de desigualdade social. Isso implica pensar o papel das representações na construção ideológica e na contestação da realidade, no âmbito de uma psicologia social do poder. Para a Howarth (2006, p. 79), as "representações sociais são mais que ferramentas psicossociais que orientam a nossa compreensão a respeito do mundo em que vivemos", pois, ao dar "suporte para uma versão particular da ordem social", elas "protegem interesses particulares de outros": representações hegemônicas e representações de oposição, do bem e do mal, do bom e do ruim. As representações sociais apresentam possibilidades para múltiplas ações e práticas sociais, como comunicar, negociar, resistir, inovar e transformar, afirma Howarth (2006, p. 68).

Todavia, esta autora avalia que existem questões subdesenvolvidas que requerem mais estudos rumo a uma teoria rigorosamente crítica, que são (Howarth, 2006): (1) o relacionamento entre processos psicológicos e práticas sociais; (2) a reificação e a legitimação de diferentes sistemas de conhecimento e (3) o papel da agência e da resistência na coconstrução da identidade e self (self-identity). Em relação ao terceiro tema, estudos sobre a relação entre representações e identidade mostram que as representações atuam na produção, na manutenção e na rejeição de identidades, dentre eles, estudos sobre identidade de gênero, identidade em comunidades multiculturais e grupos de imigrantes e estudos sobre estigmas e representações em comunidades 
localizadas em áreas com alta criminalidade e vivendo em situações de desigualdade social, e pesquisas sobre identidade com indivíduos acometidos por HIV/AIDS.

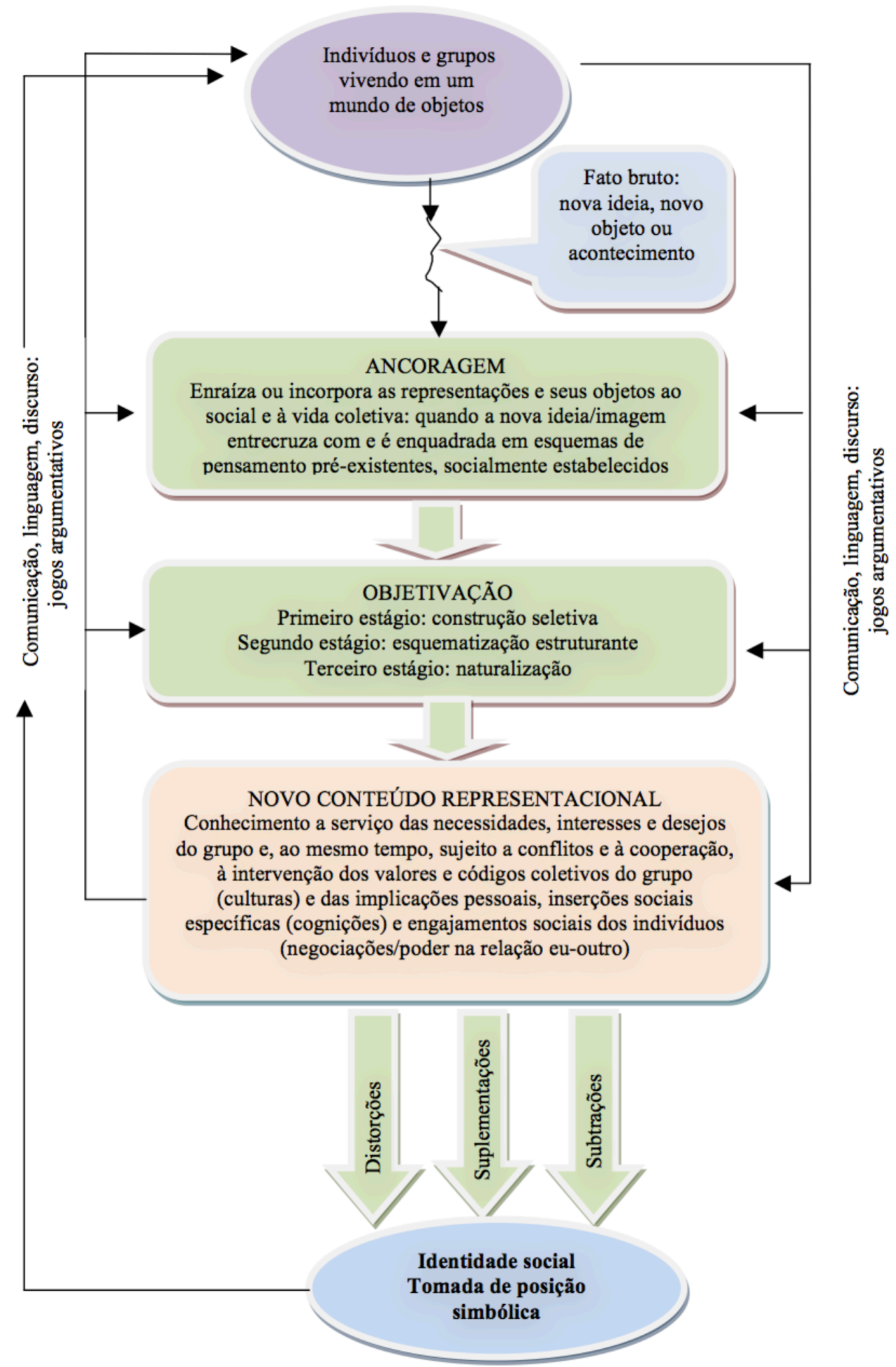

Figura 1 - Gênese e caráter prático das representações sociais Nota. Fonte: Elaborada pelos autores.

Em estudo sobre as relações sociais e os processos simbólicos no trabalho do psicólogo, Palmonari e Zani (2001) identificaram esquemas representacionais que geram significação social do trabalho desses profissionais, para eles mesmos e para os seus interlocutores. Esses esquemas combinam intervenção social e intervenção no indivíduo (eixo vertical) e vocação e profissionalismo (eixo horizontal) produzem quatro tipos de significação: escolha de vida para lutar contra as 
Representações do lucro no comércio de artigos religiosos: interpretações do sagrado e do profano no cotidiano das organizações

condições que criam a perturbação; alcançar a maturidade pessoal que permita ajudar o outro por meio da relação; analisar cientificamente a realidade para mudá-la e dispor de competências técnicas para ajudar pessoas com problemas (Palmonari \& Zani, 2001, p. 267)

As representações aplicam-se, portanto, à pesquisa de questões intergrupo (percepções, atitudes e comportamentos) e também à pesquisa de estereótipos de grupos definidos a partir de identidades étnicas e raciais (Brewer \& Kramer, 1985). As "denominações de grupo são representações" (Philogène, 2000). As representações sociais estão, portanto, enraizadas na vida social e nas interações sociais e "nós as utilizamos para posicionar a nós mesmos, para reivindicar identidades comuns e para nos defender de práticas de estigmatização e de marginalização" (Howarth, 2006, p. 78). A teoria das representações sociais permite superar o individualismo em teorias sobre identidade, ao "explorar como representações são manipuladas na (re)avaliação do grupo" e por considerar que "identidades são sempre construídas a partir e contra representações" (Howarth, 2002, p. 159).

\section{Procedimentos Metodológicos}

Nós conduzimos uma pesquisa caracterizada pela abordagem qualitativa dos dados coletados por meio de entrevista estruturada. O público pesquisado foi composto por comerciantes que produzem e/ou comercializam artigos religiosos nas quatro principais cidades da região do Triângulo Mineiro. Os artigos religiosos comercializados nos estabelecimentos correspondem a cinco denominações religiosas brasileiras: católica, evangélica, espírita, umbanda e candomblé. As duas últimas são abordadas, nesta pesquisa, de forma conjunta, conforme elas se apresentam na pesquisa de campo e também na pesquisa realizada pelo Instituto Brasileiro de Geografia e Estatística - IBGE (2010). A seleção do público da pesquisa, trinta proprietários gestores de empresas que produzem e/ou comercializam artigos religiosos, seguiu o critério de amostragem não probabilística (Goode \& Hatt, 1979) e a estratégia de caso típico (Patton, 1990).

Os entrevistados pesquisados estão distribuídos em quatro cidades da região do Triângulo Mineiro, conforme segue: 4 em Araguari, 8 em Ituiutaba, 8 em Uberaba e 10 em Uberlândia. As entrevistas foram realizadas nos seguintes períodos: de fevereiro a junho de 2012, em Ituiutaba; de junho a setembro de 2012, em Araguari; de maio a setembro de 2012, em Uberaba e de junho a setembro de 2012, em Uberlândia. As transcrições das entrevistas deram origem a um arquivo com 697 páginas. O tempo total do áudio de gravação foi de 2.011 minutos, o que significa um tempo médio de 64 minutos para cada entrevista. A distribuição dos estabelecimentos por religião, considerando a religião predominante dos artigos religiosos comercializados foi a seguinte: 9 da religião católica, 8 da umbanda/candomblé, 7 de religiões evangélicas e 6 da religião espírita. Em relação ao perfil dos entrevistados, foram entrevistados 14 homens e 16 mulheres. Ressalta-se que, por limitações de espaço, serão apresentadas neste artigo apenas aquelas falas consideradas como sendo as mais representativas das categorias de análise exploradas.

Nós elaboramos um roteiro para a realização da entrevista semiestruturada, conforme orientações de Beaud e Weber (2007), Gaskell (2010), Rubin e Rubin (1995) e Silverman (2009). O uso de um roteiro para a coleta de dados mostrou-se adequado em um processo que envolveu mais de um pesquisador. As 30 entrevistas foram realizadas na modalidade face a face. O roteiro foi estruturado a partir de quatro macrotemas, visando obter informações básicas sobre o entrevistado e a empresa; a criação da empresa e os planos para o futuro; a relação do indivíduo com a religião e a relação entre religião e as práticas organizacionais. Após a transcrição, as entrevistas foram analisadas pelo método de análise de conteúdo (Bardin, 2009; Krippendorff, 1986). Na análise das entrevistas, inicialmente, foi realizada uma leitura cética e flutuante, interrogando o texto das entrevistas. Em seguida, foi conduzida uma análise temática, a partir do que é comum ou o que distingue os textos, da presença de itens significativos, mas também da ausência de itens de significação.

Considerando a unidade de análise da pesquisa (as representações sociais do lucro no comércio de artigos religiosos) e a dimensão de análise (os processos de geração do conteúdo representacional do lucro), nós buscamos identificar, na segunda etapa da pesquisa, as defasagens que caracterizam o processo de produção daquelas representações: distorção, suplementação e subtração (as três categorias de análise).

Nós empregamos o método de análise de conteúdo para analisar a tensão representacional entre "fé-religião-sagrado" e os mecanismos de defasagem (Jodelet, 2001) que atuam e predominam sobre essa tensão para gerar representações do lucro na relação "lucro-negócio-profano". Ainda, 
analisamos a identificação (Howarth, 2006; Palmonari \& Zani, 2001) da função da atividade comercial e a identificação do papel do comerciante no contexto social produzidas a partir de uma representação social do lucro, em cada religião. Além do método de análise de conteúdo, nós empregamos pressupostos da análise de discurso francesa (Fiorin, 2003; Iñiguez, 2005; Maingueneau, 1998), pois as representações sociais dos entrevistados acerca do lucro são influenciadas pelas representações do lucro presentes no discurso de diferentes perspectivas religiosas.

Para a análise das distorções no processo de geração do conteúdo representacional do lucro, nós consideramos a seguinte definição básica de lucro: a diferença entre o valor da mercadoria e seu custo de produção, que assume exteriormente a forma de remuneração do capital investido em meios de produção e força de trabalho (Oliveira, 2004). No âmbito deste artigo, o lucro é o elemento profano e a religião é o elemento sagrado (Eliade, 2008).

\section{Apresentação e Análise dos Resultados}

Nesta seção, nós descrevemos e analisamos os resultados da pesquisa e mostramos quais representações sociais do lucro predominam na atividade comercial de cada uma das religiões pesquisadas: católica, espírita, evangélicas e umbanda e candomblé. Os resultados mostram que, conforme Geertz (2008), o caráter implícito e diretamente sentido da religião fornece significados gerais aos comerciantes, a partir dos quais eles interpretam suas experiências e organizam suas condutas em relação ao lucro.

\begin{tabular}{|c|c|c|c|}
\hline $\begin{array}{l}\text { Fé-religião-sagrado } \\
\text { Tensão } \\
\text { representacional }\end{array}$ & $\begin{array}{l}\text { Mecanismo de } \\
\text { intervenção que } \\
\text { predomina no } \\
\text { processo de } \\
\text { representação }\end{array}$ & $\begin{array}{l}\text { Lucro-negócio-profano } \\
\text { Representação do lucro }\end{array}$ & $\begin{array}{c}\text { Identificação da } \\
\text { função da } \\
\text { atividade comercial } \\
\text { e do comerciante } \\
\text { no contexto social }\end{array}$ \\
\hline $\begin{array}{l}\text { Catolicismo: tensão } \\
\text { representacional entre } \\
\text { usura e preço justo, busca } \\
\text { pela sobrevivência e } \\
\text { piedade e auxílio ao } \\
\text { próximo. }\end{array}$ & Subtração & $\begin{array}{l}\text { A função financeira e a busca } \\
\text { pela riqueza são secundárias em } \\
\text { prol da função espiritual: fazer o } \\
\text { bem para outra pessoa que } \\
\text { necessita de conforto e auxílio } \\
\text { espiritual. }\end{array}$ & $\begin{array}{l}\text { Evangelização: } \\
\text { alguém que contribui } \\
\text { com a renovação do } \\
\text { interior das pessoas. }\end{array}$ \\
\hline $\begin{array}{l}\text { Espiritismo: tensão } \\
\text { representacional do lucro } \\
\text { buscado exclusivamente } \\
\text { para benefício próprio. }\end{array}$ & Suplementação & $\begin{array}{l}\text { A função fraterna e espiritual } \\
\text { suplementa a função financeira: } \\
\text { os valores e bens adquiridos com } \\
\text { a atividade comercial seriam, } \\
\text { apenas, "instrumentos" para o } \\
\text { trabalho fraterno de auxílio ao } \\
\text { próximo. }\end{array}$ & $\begin{array}{l}\text { Doação: alguém que } \\
\text { trabalha e progride } \\
\text { para fazer bem ao } \\
\text { próximo }\end{array}$ \\
\hline $\begin{array}{l}\text { Evangélicos: tensão } \\
\text { representacional entre } \\
\text { riqueza e merecimento. }\end{array}$ & Distorção & $\begin{array}{l}\text { A função moral é dependente da } \\
\text { função financeira: se coisas } \\
\text { materiais estão sendo obtidas, } \\
\text { significa que o comerciante fez } \\
\text { por merecê-las. }\end{array}$ & $\begin{array}{l}\text { Merecimento: alguém } \\
\text { que se distingue por } \\
\text { suas qualidades } \\
\text { morais; o } \\
\text { enriquecimento é uma } \\
\text { prova disso. }\end{array}$ \\
\hline $\begin{array}{l}\text { Umbanda e candomblé: } \\
\text { tensão representacional na } \\
\text { troca entre a graça a ser } \\
\text { alcançada e a oferenda. }\end{array}$ & Subtração & $\begin{array}{l}\text { A função financeira se destaca e } \\
\text { a função espiritual é minimizada: } \\
\text { ênfase em ser um negócio } \\
\text { semelhante a qualquer outro, } \\
\text { subtração das especificidades } \\
\text { desse tipo de comércio }\end{array}$ & $\begin{array}{l}\text { Resistência: alguém } \\
\text { que se define pelo } \\
\text { bom caráter, mas que } \\
\text { ainda sofre } \\
\text { preconceito }\end{array}$ \\
\hline
\end{tabular}

Figura 2 - Representações sociais do lucro no comércio de artigos religiosos

Nota. Fonte: Elaborada pelos autores.

Nas entrevistas, os comerciantes fizeram afirmações e utilizaram diversos argumentos na tentativa de "conceber o universo inteiro como humanamente significativo", conforme analisou Berger (1985, p. 41), o que significa que a religião não apenas desempenhou, mas ainda desempenha um papel estratégico no "empreendimento humano da construção do mundo". A Figura 2 sintetiza os resultados da pesquisa, os quais mostram o enraizamento das representações sociais na vida social, especificamente nas interações sociais que ocorrem no comércio de artigos religiosos. 
Representações do lucro no comércio de artigos religiosos: interpretações do sagrado e do profano no cotidiano das organizações

Representações do mundo do sagrado e do profano dão suporte para os comerciantes, de cada religião, posicionarem-se a si mesmos e revindicarem uma identidade social (Howarth, 2006).

O catolicismo, conforme Valle (2004), passa por significativas transformações no mundo inteiro, influenciadas por estilos de vida e sistemas ou padrões religiosos de outros países, notadamente os EUA. Esse autor analisou o papel da Renovação Carismática Católica (RCC), a qual afirma ser um produto norte-americano, e afirma que, no Brasil, o catolicismo tem fortes ligações com a Europa e isso dificulta a entrada de elementos próprios do protestantismo norte-americano. O movimento da RCC promove uma "reestruturação do campo perceptivo e da autocompreensão do sujeito" com suporte em grupos de oração com os quais se busca manter o entusiasmo dos membros e atividades de formação com base em estudos da Bíblia e a orientação para ações evangelizadoras diretas, centradas "no testemunho pessoal e grupal" (Valle, 2004, p. 102). "A RCC se apresenta como sendo 'o' novo modo de ser Igreja [ ...] ela cobra de seus membros um programa de vida no qual a espiritualidade e a fidelidade doutrinal e moral católicas constituem o eixo central": transformação espiritual, mudanças na vida familiar e profissional, práticas de piedade, controle da sexualidade e abandono do que é mundano (Valle, 2004, p. 102). Essa moral difundida na RCC expressa uma visão conservadora dos processos sociais e da história, avalia o autor.

$\mathrm{Na}$ perspectiva dos comerciantes de artigos religiosos católicos, entrevistados para esta pesquisa (Figura 2), a sobrevivência é vista como condição para a manutenção das atividades da empresa. Assim, o lucro é necessário na medida em que é a partir dele que os salários dos funcionários e as demais contas são pagos. O que aparenta ser condenável para esses comerciantes é o tamanho da diferença entre o valor da mercadoria e seu custo de produção. Uma diferença pequena, na concepção desses comerciantes, comprova que o lucro é fonte de sobrevivência tanto do comerciante e de sua família, quanto do empreendimento. Assim, nessa representação do lucro, o seu uso não permite acumulação de riqueza, mas restringe-se a comer, vestir e educar. Exclui-se, daí, a utilização do lucro para fins acumulativos ou ostentatórios, o que caracterizaria o elemento da usura.

Com base em suas crenças e na ideologia católica, esses sujeitos tratam a usura como um elemento que prejudica o outro, mais especificamente o cliente, na relação de consumo. Para eles, portanto, "exagerar" na obtenção do lucro caracterizaria, do ponto de vista financeiro, o prejuízo ao próximo, e, do ponto de vista moral, aproveitar-se do outro, conforme extratos (001) e (002). Tal compreensão coloca o lucro em patamares de "sobrevivência" e, também, algo "justo", que não prejudica nem o comerciante, na manutenção de suas despesas privadas e empresariais, nem o cliente, na realização da compra de artigos religiosos com preços acessíveis.

Nós identificamos a preocupação dos entrevistados com a moralização, por meio da evangelização e de práticas de piedade. Esses conceitos aparecem forte nas falas dos comerciantes católicos e norteiam, assim, a prática organizacional em sua dimensão financeira. Além disso, a manutenção do lucro em patamares aceitáveis, na perspectiva dos dogmas religiosos do catolicismo, leva os comerciantes a caracterizá-lo, também, como "natural" e "normal", conforme extratos (003) e (004). As duas ideias e imagens do lucro: o "lucro exacerbado", que é condenado pela doutrina católica, e o "lucro normal", que é aceito e valorizado pela mesma doutrina, não funcionam apenas para os propósitos da instituição religiosa, mas também constituem um mecanismo psicossocial empregado pelo comerciante para lidar com os conflitos presentes na comercialização de produtos religiosos versus dogmas da religião, e para desenvolver sua identidade e pertencimento a um grupo social.

Tais conflitos representacionais estão presentes na produção de identidade do próprio indivíduo (Howarth, 2002, 2006; Philogène, 2000) e do negócio que ele criou e administra, ou seja, nas relações com os outros (mundo exterior) e na relação do indivíduo consigo próprio (mundo interior). Os fragmentos (005) e (007) mostram esses aspectos - "não só a igreja condena, mas o nosso interior também condena". O comerciante, orientado por esse tipo de conhecimento representacional (Spink, 1993), busca resolver o conflito interior por meio da oração - "[ ...] nas minhas orações, eu ficava é, assim, existe um conflito...". Conforme pode ser visto na seleção lexical do fragmento 007, a "resposta" para as orações vem da "intervenção divina" - "Deus colocava pra mim [ ...] que é aquela passagem que fala: 'Dai a Cesar o que é de Cesar, e a Deus o que é de Deus'". 
(001) [ ...] alguns clientes acham, porque é uma loja que tem produtos de religião, tem [ ...] eu tenho que dar de graça [ ...] por incrível que pareça. Mas, é [ ...] não tenho, eu não [ ...] nunca, como, num outro dia, eu perguntei para um padre, falei: “ô padre, uns cara, o pessoal vai lá me encher o saco, diz que [ ...] diz que eu 'tô cobrando caro e tal, mas o preço é tabelado: bíblia, CD, essas coisas, é tudo preço tabelado. Não tem como você colocar outro preço. Vem pronto lá". Aí o padre falou assim: "não, você tem que comer, você tem que vestir, tem que educar seus filhos. Então, [ ...] a religião não condena lucro nenhum, desde que ele não seja [ ...] usura (E1).

(002) [ ...] Então, a igreja condena esse lucro que, pra mim, é um dinheiro [ ...] profano aí, que não vai me valer de nada, e eu vou 'tá prejudicando o outro. (E2)

(003) [ ...] pois é. O lucro, hoje, é muito assim. Nós precisamos sobreviver. Então, eu tenho aquele lucro que é o lucro é, vamos falar assim, natural. Uma coisa que não pesa pra ninguém, uma margem boa pra mercadoria. Agora, aquele lucro exacerbado, uma coisa fora de base... aí, a religião condena não só por eu ter demais, mas que eu 'tô tirando do outro. (E2)

(004) [ ...] eu acho que [ a obtenção do lucro com a venda de produtos religiosos] é bem tranquilo, que eu acho que é bem para o sustento mesmo, pra funcionar mesmo. (E3)

(005) [ ...] pois é. O lucro, hoje, é muito assim. Nós precisamos de sobreviver, então, eu tenho aquele lucro, que é o lucro é, vamos falar assim, natural, uma coisa que não pesa pra ninguém, uma margem boa pra mercadoria. Agora, aquele lucro exacerbado, uma coisa fora de base, aí a religião condena não só pra eu ter demais, mas que eu 'tô tirando do outro. Então, um negócio custa 5, eu vendo, assim, a 25. Além de eu estar errando, para eu estar acumulando de forma errada, eu 'tô tirando daquele que, às vezes, vai apertar tudo pra poder pagar os 25. [ ...] Então, a igreja condena esse lucro que, pra mim, é um dinheiro, como foi coloca no mesmo, profano, aí, que não vai me valer de nada, e eu vou 'tá prejudicando o outro. [...] Então, esse lucro, vamos falar assim, fora de base que a gente vê, esse não só a igreja condena, mas o nosso interior também condena. (E2)

(006) [...] eu acho que tem que ser algo justo [ a quantidade do lucro], porque toda empresa tem que viver de lucro [ ...], porque senão não sobrevive, certo? Então, é uma coisa que seja justa pra mim e para o cliente. Então, você tem que fazer um paralelo aí. É uma coisa que você não pode colocar um valor muito exorbitante, certo?, que abuse e outra, se você colocar um preço muito alto, você não vende mercadoria também. Então, se quiser vender, então, tem que... Então, tem que abrir uma medida para isso aí. Não, eu vejo como uma coisa normal, como qualquer outra, sabe? Então, isso aí é a mesma coisa, como comércio, mais é uma coisa mais prazerosa porque você está sempre passando uma coisa de bom, certo? Eu tenho certeza, se você está vendendo uma bíblia, vai ler a bíblia, vai aprender! Um santo, uma imagem e tal. Então, eu acho, assim, que é mais prazerosa. (E2)

(007) [...] nas minhas orações, eu ficava é, assim, existe um conflito... existe um conflito porque, primeiro, pela minha formação, eu sei que o negócio tem que ser viável, eu tenho que gerar recursos financeiros, eu tenho que vender, eu tenho que trabalhar. É o aspecto financeiro comercial da loja. Então, assim, em termos pessoais e espirituais, no início, gerava um conflito. Então, eu sigo muito aquilo que a bi... e Deus colocava pra mim [ ...], que é aquela passagem que fala: "Dai a Cesar o que é de Cesar, e a Deus o que é de Deus" (E4)

(008) [ ...] o objetivo da venda [ ...] é para... para um bem maior [...] que quem leva o artigo, é para o bem dele. (E5)

(009) [ ...] eu acredito que ela faz isso mais por questão de evangelização mesmo. (E6)

Figura 3 - A concepção do lucro por comerciantes de artigos religiosos católicos

Nota. Fonte: Elaborada pelos autores.

Desse modo, o entrevistado 04 (fragmento 007) utilizou uma passagem bíblica como estratégia para reforçar uma concepção, segundo a qual não existe um conflito entre as condições materiais de existência do negócio e os dogmas da religião à qual o comerciante está vinculado. Para esse entrevistado, as necessidades do mundo material relacionam-se "ao que é de César", ou, àquilo que é próprio do mundo profano. O indivíduo e o negócio necessitam, para sua sobrevivência e manutenção, do dinheiro proveniente do lucro da comercialização de artigos religiosos. Ou seja, trata-se de algo justo, desde que, nesse mundo "de César", se respeitem certos dogmas religiosos, como aversão à usura (dimensão moral) e honestidade na gestão do negócio, o que significa trabalhar com uma margem reduzida entre o valor da mercadoria e seu custo de produção (dimensão financeira). Além dessas, tem-se uma dimensão espiritual: "a Deus o que é de Deus" (extrato 007), que significa trabalhar em prol da evangelização (extratos 006, 008, 009), pois comercializar uma bíblia ou outro artigo religioso é uma forma de disseminar a doutrina católica. 
Representações do lucro no comércio de artigos religiosos: interpretações do sagrado e do profano no cotidiano das organizações

No comércio de artigos religiosos católicos, nós identificamos a predominância de uma das formas de defasagem do conteúdo representacional do lucro: a subtração (Jodelet, 2001), pois a diferença entre o valor da mercadoria e seu custo de produção, base da concepção do lucro, é um aspecto reconhecido pelos entrevistados, porém, o foco do trabalho empresarial de artigos religiosos católicos deve ser manter reduzida aquela diferença. Obviamente, a doutrina não delimita os valores, mas subtrai do lucro a lógica da maximização. Essa operação interpretativa e representacional de subtração possibilita solucionar possíveis conflitos entre as dimensões financeira, moral e espiritual. Esse mecanismo de subtração também possibilita separar a dimensão material ("de César") da dimensão espiritual ("de Deus"). Para esses comerciantes, os empreendimentos têm uma função financeira (sobrevivência) e outra espiritual (fazer o bem para outra pessoa que necessita de conforto e auxílio espiritual).

Em relação aos entrevistados que comercializam artigos religiosos espíritas, conforme Figura 4, os mesmos têm uma visão também normalizada em relação ao lucro. O entrevistado 07 (fragmento 010) utilizou a repetição da negação associada às palavras "problema" e "errada" - "Não, não tem problema não" e "[ ...] o lucro não é uma coisa errada não [ ...]". O entrevistado também recorre à afirmação de que o lucro "faz parte da vida [ ...] de todo mundo". Esta última parece aproximar-se da abordagem da ideologia católica que localiza a dimensão material da vida no universo mundano/profano ("de César"). Para a ideologia espírita, o lucro é visto como consequência normal da própria atividade comercial e inerente à vida - "[ ...] o lucro é um... uma consequência normal". Tal fato pode ser visualizado nas falas do entrevistado 007 (fragmentos 010 e 011), que relacionou, por meio de elementos doutrinários da própria religião, o "dinheiro" e o "progresso" ao sangue que corre no corpo humano.

\begin{tabular}{|c|c|}
\hline 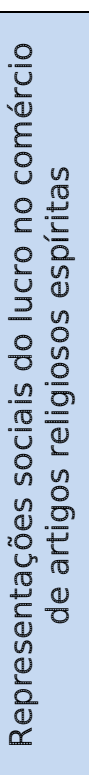 & $\begin{array}{l}\text { (010) Não, não tem problema não. Deus não... não acha ruim uma pessoa ganhar dinheiro não. Pelo } \\
\text { contrário. Assim, a... é... Deus quer a qualidade de vida para todo mundo, entendeu? [...] o lucro não é } \\
\text { uma coisa errada não, entendeu? Faz parte da vida... de todo mundo. (E7) } \\
\text { (011) o lucro... olha, é... Emanuel [ guia espiritual do médium Chico Xavier] nos ensina e a lógica } \\
\text { realmente consiste nisso..."o dinheiro “tá pro progresso igual ao sangue "tá pra saúde do corpo... ele } \\
\text { tem que movimentar", entendeu? Então, a gente, pelo menos eu, o dinheiro é muitíssimo importante. } \\
\text { Ele circula, tudo, ele... ele dá oportunidade, ele... ele é tudo... Ele, bem usado, ele realmente } \\
\text { patrocina o progresso (E7). } \\
\text { (012) [...] o lucro é um... uma consequência normal [...], dentro da filosofia espírita. o que ele } \\
\text { recrimina é o que você vai fazer com esse lucro. Então..., se você vai usar tudo em benefício próprio } \\
\text { é..., até não é discriminado usar em benefício próprio, desde que esse benefício esteja beneficiando } \\
\text { outras pessoas. (E8) } \\
\text { (013) o que o condena não só dentro do estabelecimento comercial de artigos religiosos, que é o meu } \\
\text { caso, mas em toda... atividade comercial normal, que ele condena, é a concentração de... valores, } \\
\text { assim, de lucro, em benefício de, "ah, já tenho uma casa, vou comprar uma chácara então...", "ah, já } \\
\text { tenho uma casa e uma chácara, vamos comprar um clube, uma fazenda..." não, isso não, isso é... isso } \\
\text { aí a doutrina espírita acha que o dinheiro tem que ser usado pra propiciar bem-estar e trabalho pra... }\end{array}$ \\
\hline
\end{tabular}

Figura 4 - A concepção do lucro por comerciantes de artigos religiosos espíritas

Nota. Fonte: Elaborada pelos autores.

Em relação às consequências, o lucro é visto como "normal" na atividade econômica somente na medida em que o mesmo é utilizado para o benefício ao próximo. Há uma forte ênfase, na ideologia espírita, na ideia de que o empreendimento comercial é, também, um canal de "divulgação da doutrina". A comercialização de livros no intuito de transmitir as mensagens difundidas pela doutrina espírita reveste-se de um caráter subjetivo e simbólico, na medida em que assume, em determinadas situações, primazia sobre a própria questão do lucro. A empresa, como uma possível representante da religião espírita, seria um "ideal", um negócio para "fazer circular o livro o mais rápido possível", difundindo o conhecimento e os preceitos provenientes da doutrina do espiritismo, e revelando, de uma maneira totalmente imbricada, uma representação (Moscovici, 2007) da congruência entre a empresa e a questão da religiosidade.

Ao analisar a construção (e a fragmentação) da identidade espírita no Brasil, Stoll (2004, p. 184) mostrou que essa doutrina desenvolveu relações históricas de afinidade e de crítica com o catolicismo, a umbanda e o "universo da 'nova era'. A autora analisa diferentes momentos da doutrina espírita, a partir do estudo de dois de seus representantes, Chico Xavier (trajetória 
consolidada nos anos 1950 a 1970) e Luiz Antonio Gasparetto (trajetória consolidada nos anos 1980).

No modelo de espiritualidade do primeiro, mais próximo do catolicismo e das "virtudes cristãs", estão presentes as práticas de caridade, de exemplaridade, a humildade e a renúncia (sexo, casamento e bens materiais). A mediunidade é exercida a partir da ideia de doação, afinal, "enquanto os demais fazem e acumulam para si (ou para os seus), o santo é aquele que acumula gestos e práticas de doação aos outros" (Stoll, 2004, p. 192). No modelo de espiritualidade de Gasparetto, que busca a interlocução com o "universo da 'nova era'" e assume posição crítica em relação à influência do catolicismo e à tradição kardecista, estão presentes práticas de outros sistemas simbólicos seculares e/ou religiosos, como as de autoajuda fundamentadas no tema da prosperidade e manifestação de personagem do universo da umbanda. Nos anos 1990, conforme Stoll (2004), ocorreu o rompimento entre o exercício da mediunidade de Gasparetto com a moral da doação, oriunda na ética cristã do catolicismo, e ele passou a orientar-se pela ética individualista da prosperidade.

Nas entrevistas realizadas, nós identificamos que a ética cristã do catolicismo, aquela difundida por Chico Xavier, ainda está presente nas falas da maioria dos entrevistados. Eles dizem ser condenável a concentração do enriquecimento para o benefício próprio. Conforme pode ser visto no fragmento 013, a acumulação individual privada é explicada como algo que não é bem visto pela doutrina espírita. Para esses comerciantes, os valores e os bens adquiridos com a atividade comercial seriam, apenas, "instrumentos" para o trabalho fraterno de auxílio ao próximo.

Nós identificamos, no comércio de artigos religiosos espíritas, a predominância de uma das formas de defasagem do conteúdo representacional do lucro, a suplementação, pois o lucro é visto como caminho para a divulgação da doutrina espírita. Ao negócio são conferidos atributos e conotações que não Ihes são próprios, produzindo um acréscimo de significações socialmente apreciadas como positivas (Jodelet, 2001). Diferentemente do que foi identificado nas falas dos comerciantes de artigos religiosos católicos, não existe um foco na diferença entre o valor da mercadoria e o seu custo de produção, base da concepção do lucro. A ideia é a de que se o lucro é maior, maiores são as possibilidades de ampliar a divulgação da doutrina espírita. Essa operação interpretativa e representacional de suplementação desloca o foco para o destino dado ao lucro. O foco não está nas origens, mas no uso do valor obtido com as atividades comerciais para ampliar as atividades religiosas e espirituais.

Em relação aos empreendimentos relacionados com a religião evangélica (Figura 5), não há, também, reprovação a respeito da natureza do lucro auferido. Conforme fragmento 014, o entrevistado utilizou a figura explícita da bíblia para reforçar a ideia de que a religião evangélica não reprova o lucro empresarial. O que é enfatizado pelos entrevistados é a ideia de que a usura, compreendida como ostentação e excesso do lucro, é reprovável para a ideologia protestante.

A expansão de religiões evangélicas ocorre desde o final dos anos 1980, no Brasil, informa Almeida (2011), com presença marcante na política, no mercado (indústria televisiva) e na mídia. Para esse pesquisador, existem diferentes concepções (conservadorismo e comportamento progressista) acerca da "moralidade pessoal" e dos "valores públicos" de religiões evangélicas, sobretudo o pentecostalismo. Isso ocorre, inclusive, devido à diversidade existente entre religiões nomeadas genericamente por protestantismo, que se refere tanto àqueles estruturados em congregações e forte organização comunitária (Assembleia de Deus, Batista), quanto ao pentecostalismo e neopentecostalismo (Igreja Universal, dentre outras). Além da diversidade, Almeida (2011) chama a atenção para questões de estilo de vida e comportamento. Ele afirma que essas denominações religiosas oferecem diferentes estilos de vida (roupas, costumes, hábitos) e práticas culturais (música gospel e a estética e os comportamentos a ela relacionados).

Do ponto de vista da prática religiosa, o aumento do número de igrejas da vertente pentecostal implica que muitas pessoas não sejam fieis a uma delas. O fato de as pessoas circularem por diferentes igrejas, traz implicações para a prática religiosa, dentre elas, a variação do grau de reflexão teológica, das exigências comportamentais e do emocionalismo. Isso, somado aos diferentes horários de culto, à localização de igrejas em locais urbanos de grande fluxo de pedestres, ao rodízio dos pastores nas diversas igrejas, gera um fenômeno que Almeida (2011) chama de "religiosidade de passagem", centrada na pregação do pastor. Tal comportamento mostra o aumento da "autonomia dos indivíduos" e a "desinstitucionalização da prática religiosa" (perdem espaço as relações horizontais entre os frequentadores de uma congregação, igreja e cultos) e a vida religiosa se torna mais privatizada e menos sujeita aos "ditames morais de uma comunidade religiosa" específica, ainda que se seja um fenômeno de massa. Nesse contexto, a experiência religiosa se torna menos teológica e mais "autoconhecimento" e "um voltar-se para si", orientados 
Representações do lucro no comércio de artigos religiosos: interpretações do sagrado e do profano no cotidiano das organizações

por pregações que combinam discurso de autoajuda e empreendedorismo, e por "demandas cotidianas materiais, afetivas e subjetivas" (Almeida, 2011).

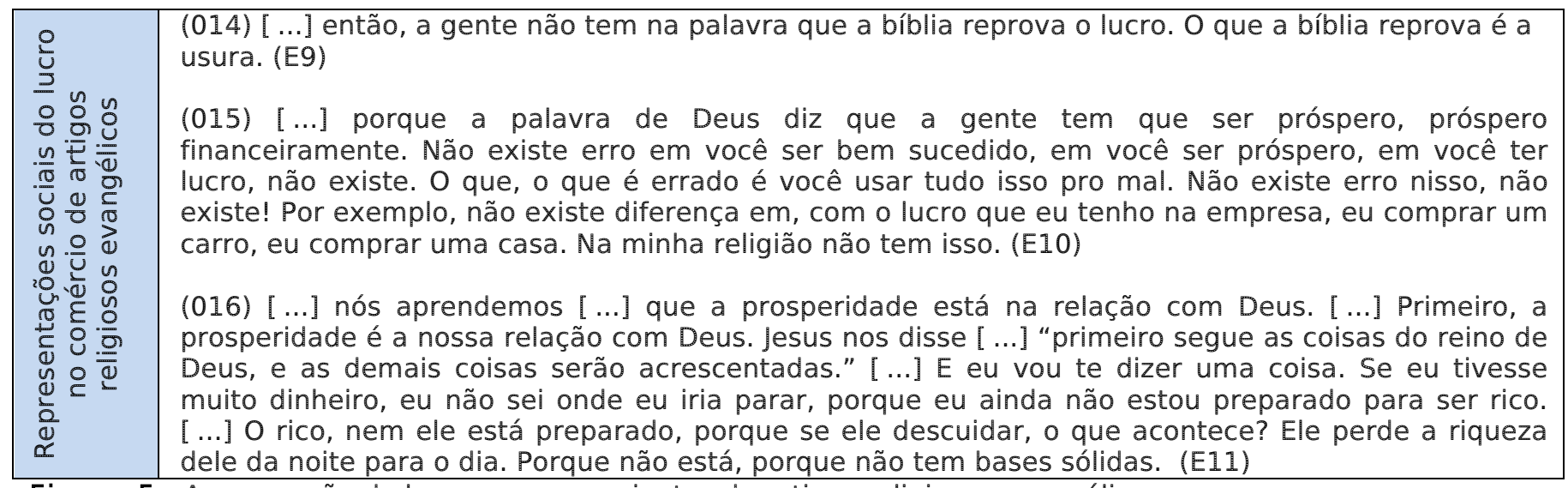

Figura 5 - A concepção do lucro por comerciantes de artigos religiosos evangélicos

Nota. Fonte: Elaborada pelos autores.

Nós identificamos uma ideia explícita nas falas dos comerciantes que mercantilizam artigos evangélicos, que é a de que a prosperidade material segue a prosperidade espiritual. Desse modo, a observância de regras morais-religiosas restritas seria, para o indivíduo, uma forma de encontrar tanto a riqueza material quanto um caminho para o autoconhecimento. Tal realidade, presente nos fragmentos (015) e (016), contrapõe-se à ideologia católica que, por meio do mecanismo de subtração, separa as duas dimensões (material e espiritual) - "A César o que é de César e a Deus o que é de Deus". Esta ideologia da prosperidade se contrapõe à moral cristã.

No comércio de artigos religiosos evangélicos predomina uma das formas de defasagem do conteúdo representacional do lucro: a distorção, que ocorre quando todos os atributos dos objetos estão presentes, porém, eles estão acentuados ou atenuados para reduzir a distância entre a representação e as qualidades socialmente desejadas para um objeto, ato ou pessoa (Jodelet, 2001 ). A diferença entre o valor da mercadoria e seu custo de produção, base da concepção do lucro, é um aspecto reconhecido pelos entrevistados e, também, a possibilidade de ficar rico com a atividade empresarial de comércio de artigos religiosos.

O mecanismo da distorção, neste caso, possibilita compreender e representar a riqueza como uma questão de merecimento. Ela reflete a natureza da relação entre o comerciante e sua relação com Deus. Por isso, o comércio de artigos religiosos não é diferente do comércio de outras mercadorias (Fragmento 015). Os empreendimentos têm uma função financeira, qual seja gerar riqueza, e uma função moral, que indica que o negócio está construído em bases sólidas e, se coisas materiais estão sendo obtidas, significa que o comerciante fez por merecê-las (Fragmento 016).

Em relação aos empreendimentos que comercializam artigos religiosos relativos à umbanda e ao candomblé (Figura 6), pode-se constatar, conforme fragmento (017), que o lucro é visto de maneira positiva. Além de ser visto de maneira positiva, o lucro é objeto de busca por parte dos gestores que utilizam práticas religiosas, para que ele seja alcançado: acender velas, tomar banho com algum tipo de produto, rezar para os santos. Nós identificamos em nossa análise das entrevistas, uma relação mais objetiva em relação à busca e à manutenção do lucro, talvez devido ao fato de que a umbanda e o candomblé não são religiões de natureza fortemente contemplativa, como o catolicismo, por exemplo. As práticas religiosas seguem, quase sempre, uma relação de troca entre a graça a ser alcançada e a oferenda, fazendo com que seja instaurada uma relação mais objetiva de troca.

Além disso, conforme fragmento (018), parece não haver dogma religioso estabelecido no candomblé e na umbanda que autorize ou desautorize o lucro empresarial. O que parece haver é, exatamente, uma constatação de que o dinheiro não é algo do mundo espiritual, mas, sim, do universo do profano. Assim, a religião não teria por objeto fomentar a prosperidade econômica do indivíduo, a qual dependerá da competência dos indivíduos e de outros fatores relacionados ao mundo dos negócios. Ainda, para esta denominação religiosa, o excesso de dinheiro não se configuraria prontamente como usura, mas em uma "prova divina" que testaria o livre-arbítrio do indivíduo. O lucro é entendido como um conceito do mundo do comércio; o preço do produto tem 
que ser explicado a partir de operações de compra e de venda. Se essas operações são realizadas de forma vantajosa ou desvantajosa, do ponto de vista dos negócios, isso refletirá nos preços.

\begin{tabular}{|c|c|}
\hline 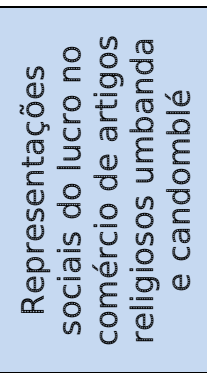 & $\begin{array}{l}\text { (017) [ ...] Ah não, na minha [ religião o lucro é visto de] forma positiva. Tanto é que, se não der } \\
\text { lucro, a gente acende vela, toma banho, reza pros santos...[ ...] (E12) } \\
\text { (018) [ ...] não, a minha religião não diz nada a respeito do lucro, não é problema da minha } \\
\text { religião. Ela não fala a respeito do dinheiro. Dinheiro não é coisa de Deus. Dinheiro é coisa dos } \\
\text { homens. Então, a religião te ajuda, para você se manter. Agora, para você ficar rica, ela nunca } \\
\text { vai te ajudar, viu? Nenhuma religião vai te ajudar para ficar rico ou para ter dinheiro em } \\
\text { excesso. Se Deus coloca dinheiro em excesso na sua mão é porque ele que ver o que você vai } \\
\text { fazer com aquele dinheiro. A quem você vai ajudar com aquele dinheiro. Dinheiro não é coisa } \\
\text { de Deus. (E13) }\end{array}$ \\
\hline
\end{tabular}

Figura 6 - A concepção do lucro por comerciantes de artigos religiosos de umbanda e candomblé

Nota. Fonte: Elaborada pelos autores.

Em relação à umbanda, Bairrão (2002, p. 57) analisa os preconceitos que cercam a sua espiritualidade: "religião degradada em práticas mágicas". Essa religião é uma criação brasileira com origens em práticas de cura dos bantos. Os seus personagens (orixás, exus, pombagiras) reforçam a necessidade de inclusão em uma sociedade caracterizada pelo conflito de classes (Haag, 2011).

Essa religião (e o primeiro terreiro de umbanda) foi fundada no Brasil em 1908. Nos anos 1970, esteve em ascensão, sobretudo com a construção de terreiros nas periferias de grandes cidades. Já nos anos 1980, iniciou-se um refluxo em seu crescimento e a perda de praticantes, em um período em que ocorreu o aumento da pobreza e a degradação da vida na periferia das metrópoles brasileiras. Para Haag (2011), à medida que cresciam as religiões pentecostais, reduzia-se a presença da umbanda no cenário religioso brasileiro. Comparativamente, a "teologia da prosperidade", difundida pela Igreja Universal, leva os indivíduos a se verem como atores econômicos responsáveis por sua salvação, enquanto a umbanda "trabalha em registros mais 'engajados' socialmente" (Haag, 2011, p. 87). A umbanda e seus personagens trabalham com o resgate da memória coletiva (Bairrão, 2002) e com a cidadania para os injustiçados ou marginalizados pela sociedade (Haag, 2011). A moralidade da umbanda é baseada na ética da justiça: os maus são punidos pelas suas vítimas, algo distante da moralidade burguesa e do pentecostalismo, motivo pelo qual passou a ser "demonizada", segundo Haag (2011).

Nós identificamos, no comércio de artigos religiosos de umbanda e candomblé, a predominância de uma das formas de defasagem do conteúdo representacional do lucro: a subtração, que ocorre quando atributos pertencentes ao objeto são suprimidos (Jodelet, 2001). Os entrevistados enfatizaram que comercializar artigos religiosos de umbanda e candomblé é um negócio semelhante a qualquer outro, minimizando, assim, as especificidades desse tipo de comércio e do lucro dele advindo. Todavia, em outras questões abordadas na entrevista, os entrevistados declararam que a sociedade tem preconceito em relação a esse tipo de comércio, à loja e a quem comercializa produtos de umbanda e candomblé. Para lidar com conflitos de identidade social, de pertencimento e de posicionamento simbólico (Moscovici, 2007; Sá, 1993), alguns deles relataram não dar muita visibilidade para algumas imagens que são vendidas na loja, colocando-as em local menos visível. Desse modo, evitam causar forte impacto para aquelas pessoas que passam pela porta da loja ou não são clientes frequentes, mas entram para comprar incenso (esoterismo) e algumas imagens (comuns com a religião católica). Também foram descritos preconceitos contra velas vermelhas e pretas e imagens de personagens dessa religião (exu).

\section{Implicações da Pesquisa e Conclusões}

Esta pesquisa foi realizada com trinta comerciantes de artigos das denominações religiosas brasileiras, catolicismo, protestantismo, espiritismo, umbanda e candomblé, em quatro principais cidades da região do Triângulo Mineiro, Uberlândia, Uberaba, Ituiutaba e Araguari. O nosso principal objetivo foi analisar quais representações sociais do lucro orientam as práticas de administração desses empreendimentos e de que modo elas são produzidas.

Os resultados mostram que as representações do lucro são produzidas a partir do uso de diferentes mecanismos de defasagem, são eles: mecanismos de distorção, suplementação e subtração. Esses são aplicados, pelos entrevistados, para lidar com tensões representacionais na relação fé-religião-sagrado. As intervenções daqueles mecanismos sobre essas tensões produzem representações do lucro que irão moldar a relação lucro-negócio-profano. As representações do 
Representações do lucro no comércio de artigos religiosos: interpretações do sagrado e do profano no cotidiano das organizações

lucro, por sua vez, produzem representações sobre a identificação da função da atividade comercial e a identificação do papel do comerciante no contexto social, em cada religião. Nós mostramos que a representação social do lucro desempenha as funções de ajuste prático do sujeito ao seu meio, de orientação da ação e de interpretação da experiência e organização da conduta no cotidiano das organizações que comercializam artigos religiosos.

Para os entrevistados que comercializam artigos religiosos católicos, o mecanismo de subtração possibilita compreender o lucro como algo "normal" e "natural" e, até mesmo "justo". O que aparenta ser condenável na ideologia católica é a extrapolação do limite do lucro, como elemento de sobrevivência tanto do comerciante e de sua família quanto do empreendimento. O lucro para a sobrevivência do comerciante e de sua família restringe-se a comer, vestir e educar. Exclui-se daí a utilização do lucro para fins acumulativos ou ostentatórios, o que caracterizaria o elemento da usura. Tal representação não afasta, no entanto, a natureza conflituosa do dilema "vender artigos com lucro" versus "dogmas religiosos", fortemente presente nos relatos dos comerciantes. Para aqueles de denominação católica, a resolução desse conflito aponta na direção de uma separação entre o universo material/mundano/profano ("de César") e o imaterial/espiritual/sagrado ("de Deus").

Em relação aos comerciantes de artigos religiosos espíritas, os mesmos têm uma visão também normalizada em relação ao lucro. Para a doutrina espírita, o lucro é visto como consequência normal da atividade comercial. O foco, porém, é dirigido ao destino dado ao lucro: a ideia de que o empreendimento comercial é um canal de divulgação da doutrina. Essa ideia mostra a predominância do mecanismo de suplementação, forma de defasagem do conteúdo representacional do lucro, no comércio de artigos religiosos espíritas. Desse modo, o empreendimento comercial adquire atributos e conotações socialmente apreciados como positivos.

Para os comerciantes de artigos religiosos evangélicos, não há, também, reprovação quanto à natureza do lucro auferido pelas empresas. O que é condenável é a ideia de usura, compreendida como excesso ou ostentação do lucro. E há uma ideia explícita para os comerciantes que mercantilizam artigos evangélicos de que a prosperidade material seria seguida pela prosperidade espiritual, ou seja, a observância de regras morais-religiosas restritas seria, para o indivíduo, uma forma de encontrar tanto a riqueza material quanto espiritual. Com a predominância do mecanismo de distorção, forma de defasagem do conteúdo representacional, são acentuados os atributos positivos da riqueza, a qual está relacionada com o merecimento e a natureza da relação do indivíduo com Deus. Desse modo, religiões evangélicas superam uma moral cristã que reprova o lucro e estimula o indivíduo a buscar a riqueza.

No comércio de artigos religiosos de umbanda e candomblé, nós constatamos que não há uma preocupação dos entrevistados com um dogma religioso que autorize ou desautorize o lucro empresarial. Neste caso, as práticas religiosas seguem, quase sempre, uma relação de troca entre a graça a ser alcançada e a oferenda, baseada em uma relação mais objetiva de troca. A prosperidade do indivíduo, o dinheiro e as coisas materiais fazem parte do mundo do comércio, não do mundo do sagrado. Há a predominância do mecanismo de subtração, pois os entrevistados enfatizam o fato de ser esse um negócio semelhante a qualquer outro, porém, especificidades desse tipo de comércio e do lucro advindo dessa atividade comercial são subtraídos e surgem somente em outras questões da entrevista, qual seja, o preconceito ainda presente nas relações sociais em relação aos indivíduos e ao estabelecimento que comercializa tais produtos, principalmente artigos para cultos de quimbanda.

As inter-relações entre administração e religião, embora ainda sejam vistas com estranhamento, têm gerado maior número de estudos acadêmicos, nos últimos anos. Um aspecto que ainda é pouco examinado diz respeito ao processo pelo qual os valores e as crenças de uma religião dão origem a uma ontologia, uma estética e uma moralidade e, por sua vez, de que modo ontologia, estética e moralidade estão presentes na ação e na conduta empresarial. A presente pesquisa se insere nesse espaço mais amplo de pesquisa e mostra que as ideias e as imagens que constituem as representações sociais de cada religião acerca do lucro influenciam o modo como cada comerciante se relaciona consigo próprio e com os outros e pode influenciar suas decisões de negócio.

Para futuras pesquisas sobre o assunto, nós sugerimos a ampliação do número de pesquisados de cada religião, de modo que se possa confirmar (ou não) a predominância dos mecanismos de defasagem representacionais aqui identificados ou, até mesmo, uma combinação de vários mecanismos. Também será valiosa a pesquisa com a inclusão de outras religiões, não analisadas 
neste estudo e, ainda, estudos comparativos entre empresas que comercializam artigos religiosos cujo proprietário não seja devoto da mesma religião dos artigos comercializados.

Embora o lucro seja visto como algo mundano e pertinente ao mundo do profano, nós mostramos que as inter-relações deste com o mundo do sagrado são fortes e variadas, ampliando as possibilidades de pesquisa em administração. Afinal, além de um escudo contra o caos, o cosmos sagrado possibilita e orienta a criação de empreendimentos e, aos indivíduos que os criaram, possibilita interpretar e atribuir significados ao lucro e à sua própria ação e conduta, diferente de uma concepção com viés economicista dos agentes econômicos, conforme mostrado nesse estudo de gestores de empresas que comercializam artigos religiosos.

\section{Nota}

1. Esta pesquisa foi financiada pela Fundação de Amparo à Pesquisa do Estado de Minas Gerais (FAPEMIG). Nós agradecemos aos dois pareceristas anônimos deste artigo por suas valiosas contribuições

\section{Referências}

Abric, J-C. (2001). O estudo experimental das representações sociais. In D. Jodelet (Org.), Representações sociais (pp. 155-172). Rio de Janeiro: EdUERJ.

Almeida, R. (2011). O que significa o crescimento evangélico no Brasil? Le monde diplomatique Brasil, 01. nov. 2011. Recuperado em

http://www.diplomatique.org.br/artigo.php?id=1045, em 12 de junho de 2014.

Bairrão, J. F. M. H. (2002). Subterrâneos da submissão: sentidos do mal no imaginário umbandista. Memorandum: Memória e História da Psicologia, 2, 55-67. Recuperado de http://www.fafich.ufmg.br/ memorandum/artigos02/bairrao01.htm, em 12 de maio de 2014.

Bardin, L. (2009). Análise de conteúdo. Lisboa: Edições 70.

Beaud, S., \& Weber, F. (2007). Guia para a pesquisa de campo. Petrópolis: Vozes.

Berger, P. (1985). O dossel sagrado. São Paulo: Paulus.

Boje, D. (2007). The little "c" catholic organization: Ecumentalism and the moral order of work. Journal of Management, Spirituality \& Religion, 4 (4), 443-460.

Boje, D. (2008). Critical Theory approaches to spirituality in business. In J. Biberman \& L. Tischler (Eds.), Spirituality in Business: Theory, Practice, and Future Directions (pp. 160-187). New York: Palgrave Macmillan.

Borges, J. F., Medeiros, C. R. O., \& Casado, T. (2011). Práticas de gestão e representações sociais do administrador: algum problema?. Cadernos EBAPE.BR, 9 (ed. especial), 530-568.

Bourdieu, P. (2007) O poder simbólico. Rio de Janeiro: Bertrand.

Bourdieu, P. (2008) A produção da crença. Porto Alegre: Zouk.

Bourdieu, P. (2010) Razões práticas. Campinas: Papirus, 2010.

Brewer, M. B. \& Kramer, R. M.(1985). The Psychology of intergroup attitudes and behavior. Annual Review of Psychology, 36, 219-243.

Cavedon, N. R., \& Pires, R. P. (2006). "O pão nosso de cada dia": as representações sociais sobre a vida familiar e profissional dos trabalhadores na indústria da panificação. Economia e Gestão, 6(12), 15-38.

Chaves, M., \& Gorski, P. (2001). Religious pluralism and religious participation. Annual Review of Sociology, 27(1), 261-281.

Cosgel, M. M., \& Minkler, L. (2004). Religious identity and consumption. Review of Social Economy, 62(3), 339-350.

Dodd, S. D., \& Gotsis, G. (2007). The Interrelationships Between Entrepreneurship and Religion. The International Journal of Entrepreneurship and Innovation, 8 (2),93-104.

Durkheim, E. (1999). As Regras do Método Sociológico. São Paulo: Martins Fontes.

Durkheim, E. (2003). As Formas Elementares da Vida Religiosa. São Paulo: Martins Fontes. 
Representações do lucro no comércio de artigos religiosos: interpretações do sagrado e do profano no cotidiano das organizações

Duveen, G. (2007). Introdução. O poder das ideias. In S. Moscovici (Org.), Representações sociais (pp. 7-28). Petrópoles: Vozes.

Dyck, B., \& Wiebe, E. (2012). Salvation, theology and organizational theory across the centuries. Organization, 19(3), 52-77.

Edgell, P. (2012). A Cultural Sociology of Religion: New directions. Annual Review of Sociology, 38(1), 247-265.

Eliade, M. (2002) Imagens e símbolos. São Paulo: Martins Fontes.

Eliade, M. (2008) O sagrado e o profano.São Paulo: Martins Fontes.

Farr, R. M. (1996). As raízes da Psicologia social moderna. Petrópolis: Vozes.

Fiorin, J. L. (2003). Linguagem e ideologia. São Paulo: Ática.

Flament, C. (2001). Estrutura e dinâmica das representações sociais. In. D. Jodelet (Org.), Representações sociais (pp. 173-186). Rio de Janeiro: EdUERJ.

Gaskell, G. (2010). Entrevistas individuais e grupais. In M. W. Bauer \& G. Gaskell (Orgs.), Pesquisa qualitativa com texto, imagem e som. (pp. 160-183). Petrópolis, RJ: Vozes.

Geertz, C. (2008). A interpretação das culturas. Rio de Janeiro: LTC.

Goode, W., \& Hatt, P. (1979). Métodos em pesquisa social. São Paulo: Nacional.

Haag, C. (2011). A força social da Umbanda. Pesquisa FAPESP, 188, out., 85-89. Recuperado de http://revistapesquisa.fapesp.br/wp-content/uploads/2011/10/084-089-188.pdf, em 12 de junho de 2014.

Howarth, C. (2002), Identity in Whose Eyes? The Role of Representations in Identity Construction. Journal for the Theory of Social Behaviour, 32(2), 145-162.

Howarth, C. (2006). 'A social representation is not a quiet thing': Exploring the critical potential of social representations theory. British Journal of Social Psychology, 45(1), 65-86.

Instituto Brasileiro de Geografia e Estatística - IBGE (2010). Séries Históricas e Estatísticas. Recuperado em 01 março, 2014, de http://www.ibge.gov.br/home/download/estatistica.shtm

Iñiguez, L. (2005). Manual de Análise do Discurso em Ciências Sociais. Belo Horizonte: Vozes.

Jahoda, G. (1988). Critical notes and reflections on 'social representations'. European Journal of Social Psychology, 18(3), 195-209.

Jodelet, D. (2001). Representações sociais: um domínio em expansão. In D. Jodelet (Org.), Representações sociais (pp. 17- 44). Rio de Janeiro: EdUERJ, 2001.

Jovchelovitch, S. (1996). In defense of representation. Journal for the Theory of Social Behaviour, 26(2), 121-135.

Kauanui, S. K., Thomas, K. D., Rubens, A. \& Sherman, C. L. (2010). Entrepreneurship and Spirituality: a comparative analysis of entrepreneur's motivation. Journal of Small Business and Entrepreneurship, 23 (4), 621-635.

Krippendorff, K. (1986). Content analysis. Beverly Hills, London: Sage Publications.

Lesbaupin, I. (2010). Marxismo e religião. In F. Teixeira (Org.), Sociologia da Religião. (pp. 78-95). Petrópolis: Vozes.

Lescura, C., Brito, M. J., Borges, A. F., \& Cappelle, M. C. A. (2012). Representações Sociais sobre as Relações de Parentesco: estudo de caso em um grupo empresarial familiar. Revista de Administração Contemporânea, 16(1), 98-117.

Maingueneau, D. (1998). Termos-chave da análise de discurso. Belo Horizonte: UFMG.

Mariz, C. L. (2010). A sociologia da religião de Max Weber. In F. Teixeira (Org.). Sociologia da Religião (pp. 51-77). Petrópolis: Vozes.

Martinelli, A. (1995). Entrepreneurship and Management. In N. J. Smelser \& R. Swedberg (Orgs.). The Handbook of Economic Sociology (pp. 476-503). Princeton: Princeton University Press.

Marx, K. \& Engels, F. (2001). A ideologia alemã. São Paulo: Martins Fontes. 
Mitroff, I. (2003). Do not promote religion under the guise of spirituality. Organization, 10(20), 375382.

Moscovici, S. (1988). Notes towards a description of Social Representations. European Journal of Social Psychology, 18(3), 211-250.

Moscovici, S. (2007). Representações sociais. Petrópoles: Vozes.

Oliveira, C. A. T. (2004). A economia com todas as letras e números. Belo Horizonte: Mercado Comum.

Ortner, S. B. (2007). Subjetividade e crítica cultural. Horizontes Antropológicos, 13(28), 375-405.

Palmonari, A. \& Zani, B. (2001). As representações sociais no campo dos psicólogos. In D. Jodelet (Org.), Representações sociais (pp. 261-279). Rio de Janeiro: EdUERJ.

Park, J. Z., \& Baker, J. (2007). What would Jesus buy: American consumption of religious and spiritual material goods. Journal for the Scientific Study of Religion, 46(4), 501-517.

Patton, M. Q. (1990). Qualitative evaluation and research methods. Newbury Park: Sage Publications.

Philogène, G. (2000). Blacks as 'serviceable other'. Journal of Community \& Applied Social Psychology, 10(5), 391-401.

Rubin, H. J., \& Rubin, I. S. (1995). Qualitative interviewing. Thousand Oaks: Sage Publications.

Sá, C. P. (1993). Representações Sociais: o conceito e o estado da atual teoria. In M. J. P. SPINK (Org.), O Conhecimento no Cotidiano (pp.19-45). São Paulo: Editora Brasiliense.

Sá, C. P. de, \& Arruda, A. (2000). O estudo das representações sociais no Brasil. Revista de Ciências Humanas, 19 (Ed. especial), 11-31.

Sanchis, P. (2001). Desencanto e formas contemporâneas do religioso. Ciências Sociais e Religião, $3(3), 27-43$.

Schwarzkopf, S. (2012). The market order as metaphysical loot: Theology and the contested legitimacy of consumer capitalism. Organization, 19(3), 281-297.

Serafim, M. C., Martes, A. C. B., \& Rodriguez, C. (2012). "Segurando na mão de Deus": organizações religiosas e apoio ao empreendedorismo. Revista de Administração de Empresas, 52(2), 217-231.

Sherkat, D. E., \& Ellison, C. G. (1999). Recent developments and current controversies in the sociology of religion. Annual Review of Sociology, 25(1), p.363-394, 1999.

Silva, A. R. L., Carrieri, A. P., \& Junquilho, G. S. (2011). A estratégia como prática social nas organizações: articulações entre representações sociais, estratégias e táticas cotidianas. Revista de Administração, 46(2), 122-134.

Silverman, D. (2009). Interpretação de dados qualitativos. Porto Alegre: Artmed.

Stoll, S. J.(2004). Narrativas biográficas: a construção da identidade espírita no Brasil e sua fragmentação. Estudos Avançados, 18(52), 181-199.

Spink, M. J. (1993). O estudo empírico das representações sociais. In: M. J. P. Spink (Org.), O Conhecimento no Cotidiano (pp. 85-108). São Paulo: Brasiliense.

Tracey, P. (2012). Religion and Organization: A critical Review of current trends and future directions. The Academy of Management Annals, 6(1), 87-134.

Valle, E. (2004). A renovação carismática católica. Algumas observações. Estudos Avançados, 18(52), 97-107.

Wagner, W. et al. (1999). Theory and method of social representations. Asian Journal of Social Psychology, 2(1), 95-125.

Weber, M. (2001). A ética protestante e o espírito do capitalismo. São Paulo: Pioneira.

Weber, M (2006). Sociologia das religiões. Lisboa: Antropos.

Zelekha, Y; Avnimelech, G; Sharabi, E. (2014) Religious institutions and entrepreneurship. Small Business Economy, 42(1), 747-767. 